\title{
Policy Implementation of Tree Management in Public Green Open Spaces, Green Lines and Parks in Semarang City
}

\author{
Kismartini ${ }^{1}$, Elita Nugraheni ${ }^{2}$ \\ $\left\{\right.$ kis_martini@yahoo.co.id $\left.{ }^{1}\right\}$ \\ Universitas Diponegoro, Indonesia ${ }^{1,2}$
}

\begin{abstract}
Development is an effort made in the context of managing and utilizing resources to improve the quality of life of an area, both on a central and regional scale. This happened to the city of Semarang, which continued to carry out development related to infrastructure and the management of its governance. However, currently there is still often destruction of the environment to achieve certain development goals. Such as felling trees in public green open spaces that are less controlled or carried out without permission from the relevant agencies. Related to this, the Semarang City Government issued Semarang City Regulation Number 8 of 2016 concerning Management of Trees in Public Green Open Space, Green Lane Roads and Parks in the City of Semarang, where there are prohibitions related to illegal logging. Regulations are made so that there are no communities that cut trees illegally, where if caught, they must receive sanctions in accordance with existing rules. Illegal loggers generally only prioritize their own interests without thinking about the adverse effects that will occur on the environment due to these irresponsible actions. This study uses an empirical method, which discusses the implementation of tree management policies in public green open spaces, green lanes and parks in the city of Semarang carried out by the City Government and the community, and what legal actions are given by the City Government against people who commit illegal loggers. This paper concludes that the felling of trees in public green open spaces, green lanes, and parks should only be done with permission from the Department of Housing and Settlement Areas of Semarang City. In this case, if the community (as the reporter or the applicant) wants to cut down trees, they must first submit an application letter to the Semarang City Housing and Settlement Office.
\end{abstract}

Keywords: Policy Implementation, Tree Felling Services.

\section{Introduction}

Regional Development is increasing from time to time in order to improve the welfare of its people. Increasing regional development results in excessive and uncontrolled use of natural resources, resulting in environmental damage. Therefore, we need to maintain and preserve this environment so that damage does not occur as a result of human negligence and greed to exploit nature. In accordance with Law Number 26 of 2007 concerning Spatial Planning and Law Number 32 of 2009 concerning Environmental Protection and Management which is further elaborated in the Semarang City Regional Regulation on Tree Management in Public Green Open Spaces, Public Green Lines, and Parks in Semarang City. In 1 number 2 of the Minister of Home Affairs Regulation Number 1 of 2007 concerning the Arrangement of 
Green Open Spaces in Urban Areas, namely Green Open Spaces in Urban Areas is part of the open space of an urban area filled with plants and plants to support ecological, social, cultural, economic benefits, and aesthetics. Green open spaces consist of public green open spaces and private green open spaces, while city parks are included in the category of public green open spaces owned and managed by the municipal government that is used for the benefit of the general public.

Trees in urban areas are a very important biological source so that they can be seen because urban areas such as Semarang city, because Semarang city is not an agricultural area, must establish a greening system that requires the presence of plants including trees in relation to the needs of urban areas. Based on this, the Semarang City Government issued the Semarang City Regulation Number 7 of 2010 concerning Green Open Space Arrangement and Semarang City Regulation Number 8 of 2016 concerning Tree Management in Public Green Open Space, Green Roads, and Roads. With this regulation, it is expected to reduce illegal logging and community participation in maintaining, maintaining and improving tree functions, and to report to the Office when they find out that there are residents who cut or damage trees in public green open spaces, green lanes, and parks in the city of Semarang. The illegal loggers generally only prioritize their own interests without thinking about the adverse effects that will occur in the surrounding environment. As has happened lately, illegal logging is still happening in Semarang City, this has resulted in environmental damage, disruption to spatial planning and city planning in Semarang City. As a result of heavy rains such as landslides and floods, various government efforts to re-preserve the environment that has been very damaged by the actions of people who are less responsible.

In line with its implementation, policies through this Regional Regulation require improvements. Therefore, this writing in order to find out the problems that accompany it as an effort to get a way out. In addition, the implementation of this policy requires a number of information from the public who have obtained information on services that have been regulated in Regional Regulation No. 8 of 2016 concerning tree management in public green open spaces, green roads and parks in the city of Semarang, and what are the procedures that must be met in order to be able to cut trees.

\subsection{Goals}

In accordance with the background that has been formulated above, this paper was made with the aim of knowing the implementation of Regional Regulation No. 8 of 2016 concerning tree management in public green open spaces, green lanes of roads and parks, and regulation of tree felling mechanisms in Semarang City carried out by the government and society.

\subsection{Problems}

a) What are the conditions for cutting down trees set by the Semarang City government?

b) How is the implementation of Semarang City Regulation Number 8 of 2016 concerning tree management in public green open spaces, public green lines and parks in Semarang City? 


\section{Methods}

The method used in writing is an empirical method, which is done by studying and collecting data from libraries related to tools, both in the form of books and information on the internet. The nature of this research is the literature review, which is where the author obtains successful observations of several books, print media, visual media, and audiovisual media. In this paper, the use of the method is to get a clear picture and find materials and problems in the form of data on the implementation of tree management in public green open spaces, green lanes, and parks in the Department of Housing and Settlements of Semarang City based on local regulations Number 8 of 2016.

\section{Results and Discussion}

\subsection{Tree felling requirements established by the Semarang City Government}

In accordance with Semarang City Regulation Number 8 of 2016 concerning Management of Trees in public green open spaces, green lanes of roads and parks, as well as the Decree of the Head of Housing and Settlements of Semarang City Number 522.5/6511 of 2018 concerning Tree felling Service Standards (Fig. 1.), in the event that tree felling cannot be done arbitrarily. The felling of trees in Semarang City must meet the conditions set by the Semarang City Government as follows:

a) Administrative requirements, consisting of:

- Photocopy of Applicant's KTP.

- Photocopy of Decree of IMB along with the attached picture if the felling of trees is related to building activities.

- Photocopy of business permit/SIUP for business actors.

- Photocopy of permission to connect the access road.

- Signing the declaration will fulfill all obligations in granting a Tree felling permits.

b) Technical requirements, consisting of:

- A description of the purpose and objectives of felling trees.

- Felling location.

- Number and species of trees to be felled; Equipment to be used in felling trees.

- Implementation and timing of tree felling activities.

- Plans for the number and types of replacement trees along with tree maintenance.

- Pictures/Photos of locations and trees to be felled.

Applicable Tree Cutting Permit is only valid for 1 (one) tree felling, with the location and number of trees stipulated in the Tree felling Permit issued by the Head of Housing and Settlement Area of the City of Semarang, and the Applicant to carry out felling of trees controlled by the Government for certain reasons, outside the trees that are porous and which are very dangerous to the community environment with consideration of:

a) Complaints from community reports on trees that are porous and generally harmful.

b) Requests from relevant agencies are accompanied by reasons. 


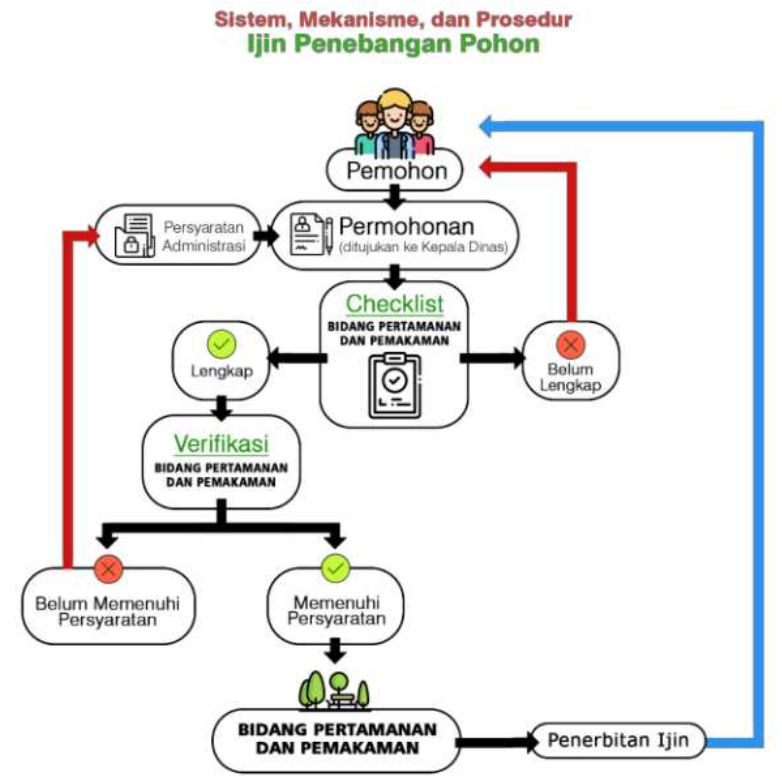

Fig. 1. System, Mechanism and Procedure Tree Felling Permit.

The technical processing of the request includes: The concerned/interested party submits the application letter to the Mayor through the Head of the Semarang City Housing and Settlements Department, with a settlement period set of 10 (ten) working days after the requirements have been declared complete and correct. The form of the Permit is in the form of a Tree felling permit, then the period of permit completion is 6 (six) days depending on the complete requirements.

Sanctions given for felling trees in public green open spaces, green lanes, and parks, in regional regulations are only administrative sanctions, which consist of:

a) Warning.

b) Government coercion.

c) Revocation of Tree felling Permit.

3.2 Implementation of Regional Regulation Number 8 of 2016 concerning Tree Management in Public Green Open Space, Green Roads and Parks in the City of Semarang

\subsubsection{Public Policy}

We simply understand these rules or regulations as public policy, so we can interpret this public policy as a law. However, it is not just law but we must understand it fully and correctly. When an issue that concerns a common interest is deemed necessary to be regulated, the formulation of the issue becomes a public policy that must be carried out and prepared and agreed upon by the authorized officials. When public policy is determined to be a public policy; whether it becomes a law, whether it becomes a government regulation or a presidential regulation including a regional regulation, then the public policy changes into law that must be obeyed. Meanwhile, public policy experts define that public policy is everything 
that is done or not done by the government, why a policy must be done and whether the benefits of living together must be a holistic consideration so that the policy contains great benefits for its citizens and has little impact and should do not cause adverse problems, however, there must be some who benefit and some are disadvantaged, this is where the government must be wise in determining a policy [1]. Meanwhile, Thoha [2] provides an interpretation of public policy as a result of the formulation of a government. In this view, public policy is better understood as what is done by the government rather than the process of results made. As according to Wahab [3] states regarding public policy, are as follows:

a) Public policy is more a conscious action-oriented towards achieving goals rather than as a behavior/action that is carried out randomly and accidentally.

b) The public policy basically consists of actions that are interrelated and have a certain pattern that leads to the achievement of certain goals carried out by the government, and not an independent decision.

c) Public policy regarding activities/actions that are deliberately carried out consciously and measurably by the government in certain fields.

d) Public policy may be positive in the sense that it is a guideline for government action to be taken in dealing with a particular problem, or negative in the sense that it is a decision of government officials not to do something.

Based on this opinion, public policy can be defined as a series of conscious, directed, and measurable activities carried out by the government involving stakeholders in certain fields that lead to certain objectives. So that for the effectiveness of public policies needed socialization activities, implementation, and supervision of policies. So it can be concluded that the nature of the public policy is:

a) Compel.

b) Binding.

c) Flexible, can be improved according to the development dynamics of development.

\subsubsection{Public Policy Implementation}

According to Edwards III, policy implementation can be interpreted as a part of the policy process stage, whose position is between the stages of policymaking and the consequences of that policy (output, outcome). Furthermore, Edward III identified aspects that were allegedly contributing to the implementation of policies, namely: communication, resources, disposition or attitude of implementers, and bureaucratic structure. The four aspects affect the implementation of the policy, both directly and indirectly, and each aspect influences each other [4].

a) Authority/Bureaucratic Structure

Authority is legitimacy for the implementers in implementing policies that are determined politically [5]. This authority is related to the bureaucratic structure inherent in the position/strata of the institution or individual as implementing the policy. The main characteristics of bureaucracy are generally contained in work procedures or Standard Operating Procedures (SOP) and organizational fragmentation.

b) Communication

Communication is an activity that results in other people interpreting an idea/ideas, especially those intended by the speaker or writer through a system that is common with symbols, signals, and behavior [6]. Communication affects the implementation of public policies, where bad communication can have adverse impacts on the implementation of policies. Dimensions of communication that can affect the implementation of public 
policies include transmission, consistency, and clarity [7]. Achieving successful implementation of public policies requires implementers to know what needs to be done clearly; the goals and objectives of the policy must be informed to the target group (target group) so as to reduce the gap between the plan and the implementation of the policy. If the delivery of information about the goals and objectives of a policy to the target group is not clear, it is possible to have resistance from the target group [5]. Communication skills are directed so that the implementers of activities can negotiate with each other and find points of understanding/consensus that are mutually beneficial. Awakened consensus can improve personal performance at work by finding a win-win condition for each problem [8].

c. Resource

Implementation of policies must be supported by the availability of resources (human, material, and method). The implementation of public policies needs to be done carefully, clearly, and consistently, but if the implementers lack the necessary resources, then the implementation of the policies will tend not to be implemented effectively. Without resource support, policies will only be a document that is not realized to provide solutions to existing problems in the community, or efforts to provide services to the community. Thus, resources are an important factor in implementing public policy. Resources in implementing public policies include adequate staffing, information, funding, authority, and other supporting facilities [5].

d. Disposition from the executor

Disposition is the character and characteristics possessed by policy implementers, such as commitment, discipline, honesty, intelligence, and democratic nature [3]. If the policy implementer has a good disposition, then he is strongly suspected that he will run the policy well, conversely, if the policy implementer has an attitude or perspective that is different from the purpose and direction of the policy, then it is possible that the process of implementing the policy will not be effective and efficient. Disposition or attitude of the implementers will cause support or obstacles to the implementation of policies depending on the suitability of the competencies and attitudes of the implementers. Therefore, the selection and determination of personnel implementing policies are required by individuals who have the right competence and dedication to the policies that have been set [5].

Furthermore, Subarsono [9] collected several theories regarding variables that affect the implementation of public policy, including:

a) Merilee S. Grindle's Theory

The implementation of public policy in Merilee S. Grindle's theory is influenced by two large variables, namely: the content of policy; and the implementation environment (context of implementation). These variables include the extent to which the interests of the target groups are stated in the contents of the policy; types of benefits received by the target group; the extent of desired changes in a policy; whether the location of the program is correct; whether a policy has detailed implementation of it; and whether a program is supported by adequate resources [9].

b) Daniel A. Mazmanian and Paul A. Sabatier's Theory This theory states that there are three groups of variables that influence the successful implementation of public policies, namely: the characteristics of the problem (tractability of the problems), the characteristics of the policy/law (ability of statute to structure implementation), and environmental variables (non-statutory variables influence implementation) [9]. 
c) Donald S. Van Meter and Carl E. Van Horn's Theory Meter and Horn Theory states at least five variables found that affect the performance of public policy implementation, namely: policy standards and objectives; resource; communication between organizations and strengthening activities; implementing agent characteristics; and social, economic and political conditions [9].

Based on several concepts and the nature of actions relating to the implementation of the policy and to find out the success or failure of the policy, it can be seen by means of the principles of good governance, including:

a) Consistency

The implementation of the policy takes place properly if the implementation of the policy is carried out consistently by adhering to the prevailing procedures and norms [10].

b) Transparency

Transparency is freedom of access to information that should be known by the public and/or interested parties [11]. Information regarding the implementation of public policies needs to be done open, easy, and accessible to all parties who need, and provided adequate, and easy to understand [12].

c) Accountability

Every activity in implementing public policies must be accountable both administratively and substantively, in accordance with statutory provisions [12].

d) Justice

Justice, in general, can be understood as kindness, virtue, and truth, which binds members of the community in realizing harmony between the use of rights and the implementation of obligations [13]. Justice in public policy is manifested in nondiscriminatory service activities. The implementation of public policy does not differentiate the quality of services in the target group based on consideration of ethnicity, race, religion, class, social status, etc. [12].

e) Participatory

Community participation is the involvement and participation of the community in implementing policies. Community participation in addition to supporting the implementation of policy decisions, on the other hand, will have an impact on the evaluation/control of government performance and can be able to minimize the abuse of authority. Community participation is the key to success in implementing public policy because participation involves aspects of supervision and aspirations. Supervision meant here includes the supervision of the executive through the legislature [11]. Based on the description, the implementation of the policy should be participatory, namely the implementation of policies that can encourage community participation by taking into account the aspirations, needs, interests, and hopes of the community [12].

f) Effectiveness

Effectiveness regarding the achievement of predetermined results, or the achievement of objectives from the implementation of actions, which are related to aspects of technical rationality, and always measured from the product or service unit [14]. In the implementation of public policy, effectiveness is measured by the success of achieving the goals and objectives set in public policy.

g) Efficiency

Efficiency refers to the amount of use of resources needed to produce a certain level of effectiveness. Efficiency is the relationship between effectiveness and resource use [14]. Size indicators that can be used on the efficiency dimension are the use of resources 
needed to achieve the goals set, which can be measured by the level of use of time, cost, people, equipment, and other resources.

In addition Nugroho [15] acknowledged that there was no best implementation model. But each type of public policy requires a different model of policy implementation. Thus to choose the best model by considering 4 (four) things as follows: First it concerns the questions 1) whether the policy is appropriate, 2) whether the policy has been formulated in accordance with the character of the problem to be solved, 3) whether the policy has been made by authorized institutions that are in accordance with the character of the policy. Second is the proper implementation. Third is right on target, including; 1 ) whether the intervened targets are as planned, 2) whether the targets are ready to be intervened or not, 3) whether the policy implementation interventions are new or updating the previous policy implementation. And fourth is the right environment, there are two most decisive environments namely the policy environment and the external environment.

Based on observations in the field and interviews with informants related to the implementation of Regional Regulation Number 8 of 2016 concerning tree management in public green open spaces, green roads and parks in the city of Semarang, we can convey as follows:

First, since the enactment of the regional regulation in the Semarang city area, direct socialization was carried out by the Semarang City Housing and Settlement Region Office to the organizers and the community as potential service users. For this reason, information dissemination was conveyed through mass media and face-to-face with community representatives from each sub-district and sub-district. In addition, the Semarang City government opened the widest possible community participation to play a role in supporting and implementing the Perda. Another thing revealed in the interview was the positive response from the community members to take part in the socialization. socialization with various internal and external resources through collaborative program management with internal implementing apparatus in the field of Parks and Cemeteries, between related agencies (Office of Spatial Planning, Office of Public Works, and Office of Environment), sub-districts, subdistricts, and communities (RT/RW) as well as Dinas office partners to succeed the implementation of Semarang City Government's policy, Semarang City Regulation Number 8 of 2016 concerning Management of Trees in Public Open Space, Green Roads and Parks in the City of Semarang.

Secondly, with the Tree felling Service Standards providing clear clarity of procedures, costs, and service products as well as legal certainty for the community members who propose cutting down trees, this is needed because there are still many residents who do not understand the procedure for proposing felling trees which previously often carried out cutting trees with own initiative.

Third, residents' complaints when proposing to cut down trees are implementation time which tends to belong, with the reason there are still many queues and if they want faster it is usually done on holidays (Saturday and Sunday) there are only special costs that are not supposed to.

Fourth, several informants said that for the suburbs of Semarang it requires a special amount of time for the applicant to send a letter to the Housing and Settlement Office and for its implementation it cannot be immediately scheduled, so it must go back and forth to the Office if it has not been followed up.

Fifth, in implementing the Perda there are still many Semarang City people who do not know or understand the contents of these regional regulations. This results in costs incurred 
for felling trees which should be free and those who file for logging are required to replace trees.

Sixth, complaints from the implementing apparatus/Housing and Settlement Areas, where the implementing apparatus complained that the demand for tree felling from the community tends to increase but the Office infrastructure (operational cars, tree cutting machines, field technical personnel) to do logging is still limited, so many logging requests trees cannot be carried out immediately, it takes a long time because according to the queue list made by the executing field.

Referring to the understanding of public policy and the model of public policy implementation George Edward III [16] approach is formulated with four factors which are the main requirements for the success of the implementation process, namely communication, resources, bureaucratic or implementing attitude and organizational structure, including governance bureaucratic work. These four factors can be concluded as follows:

First, shows that Regional Regulation Number 8 of 2016 concerning Management of Trees in Public Green Open Spaces, green lines of roads and parks is a public policy made by the Semarang City government especially the Housing and Settlement Areas as the implementation, in order to control tree felling in the Semarang City area by involving stakeholders who aim to maintain and preserve a good and healthy public green open space environment. As well as providing legal certainty for the Department of Housing and Settlement Areas to regulate the felling of trees on public green open spaces, green lanes, and parks in the city of Semarang.

Second, communication activities in the form of socialization with various internal and external resources through collaborative program management with internal implementing apparatus in the field of Parks and Cemeteries, between related agencies (Spatial Planning Office, Public Works Agency, and Environmental Agency), sub-districts, urban villages and community (RT/RW) as well as Dinas working partners to succeed the implementation of the Semarang City government policy namely Semarang City Regulation Number 8 of 2016 concerning Tree Management in Public Open Spaces, Green Roads and Parks. In addition, the attitude of the Department of Housing and Settlement Officers who asked for support or community participation in preserving the environment.

Third, the resources owned by the Department of Housing and Residential Areas, are the work areas that must be provided with tree felling services throughout the City of Semarang, and the infrastructure needed in the implementation of tree felling services, both administrative and technical.

Fourth, look at the attitude of the bureaucracy or executor at the Department of Housing and Settlements of the City of Semarang in carrying out their duties in accordance with the functions of their functions, which in working based on the Program Operational Standards (SOP) that are mutually agreed upon.

Fifth, the suitability of the organizational structure allows the implementation of services is not complicated, and only within the scope of the Department of Housing and Settlements of the City of Semarang, without involving other Dinas for the implementation of felling trees.

In addition to conformity with the several models of implementation of the regulation, based on the aspects stated in the principles of good governance, the existence of Regional Regulation Number 8 of 2016 is suitability for consistency, transparency, accountability, fairness, participatory, effectiveness and efficiency, which is one of the benchmarks its success is increasing public awareness in complying with these rules, for example before logging, always submit a request for tree felling first to the Department of Housing and Settlements of the City of Semarang. 


\section{Conclusion}

Based on the observations made by the author, it can be concluded: First, the tree felling SOP covers procedures that need to be considered and fulfilled in fulfilling the tree felling requirements, in Semarang City must meet the conditions set by the Semarang City Regional Government, including:

a) Administrative Requirements

b) Technical Requirements

Secondly, that the implementation of tree management policies on public green open spaces, green roads and parks in the city of Semarang, can be said to be successful, due to increasing public awareness to protect and preserve the surrounding environment, by reducing arbitrary actions in felling trees. And increasing public awareness when going to cut trees submit a letter of application in advance to the Department of Housing and Settlements of the City of Semarang.

Third, the obstacles faced include: Ignorance of the people related to the system, mechanism, and procedure for felling trees; The level of demand for tree felling is getting higher, but the availability of facilities and infrastructure for tree felling is still limited; and the application system that is still conventional (not based on online) which makes the flow of submissions run longer, especially submissions originating from the edge of the city.

\section{References}

[1] T. A. Dye, D. Roskell, R. Simpson, M. Asal, K. M. Guttag, N. Tebbutt, and J. Van Aken, "Data processing apparatus with self-emulation capability." Google Patents, 18-Aug-1992.

[2] M. Thoha, Birokrasi pemerintah dan kekuasaan di Indonesia. Thafa Media, 2012.

[3] S. A. Wahab, "Pengantar Analisis Implementasi Kebijakan Negara," Jakarta: Rineka Cipta, 2010.

[4] E. Wahyudi, W. Yulianingsih, and M. F. Sholihin, Hukum ketenagakerjaan. Sinar Grafika, 2016.

[5] M. I. Afandi and W. Warjio, "Implementasi Peraturan Daerah Kabupaten Asahan Nomor 11 Tahun 2011 Tentang Pajak Daerah Dalam Pencapaian Target Pajak Bumi Dan Bangunan Perdesaan Dan Perkotaan (Studi Deskriptif Di Kelurahan Bunut Barat Kecamatan Kota Kisaran Barat)," J. Adm. Publik (Public Adm. Journal), vol. 5, no. 2, pp. 132-153, 2015.

[6] A. P. Wardhani, L. B. Hasiholan, and M. M. Minarsih, "Pengaruh Lingkungan Kerja, Komunikasi dan Kepemimpinan Terhadap Kinerja Pegawai (Studi Kasus di Dinas Kebudayaan dan Pariwisata Kota Semarang)," J. Manage., vol. 2, no. 2, 2016.

[7] B. Winarno, Kebijakan publik: teori, proses, dan studi kasus: edisi dan revisi terbaru. Center for Academic Publishing Service, 2012.

[8] M. A. Ramdhani and K. Suryadi, "Consensus method development on analytic hierarchy process," in International Conference on Quantitative Sciences and Its Applications, 2005, pp. $1-10$.

[9] A. G. Subarsono, “Kebijakan Publik: Konsep, Teori, dan Aplikasi.” Jogyakarta: Pustaka Pelajar, 2011.

[10] M. Mutiasari, M. N. Yamin, and S. Alam, "Implementasi Kebijakan Perizinan Dan Pemberitahuan Kegiatan Masyarakat Pada Kepolisian Resort (Polres) Kota Kendari," Publica J. Adm. Pembang. dan Kebijak. Publik, vol. 7, no. 1, 2016.

[11] I. Coryanata, "Akuntabilitas, partisipasi masyarakat dan transparansi kebijakan publik sebagai pemoderasi hubungan pengetahuan dewan tentang anggaran dan pengawasan keuangan daerah," J. Account. Invest., vol. 12, no. 2, pp. 110-125, 2016. 
[12] A. T. Rohman, "Implementasi Kebijakan Melalui Kualitas Pelayanan Penerimaan Pajak Daerah Dan Implikasinya Terhadap Kepuasan Masyarakat Di Dinas Pendapatan Kabupaten Kuningan (Studi Peraturan Daerah Kabupaten Kuningan No. 15 Tahun 2010 Tentang Pajak Daerah)." UNPAS, 2016.

[13] B. J. Nasution, "Kajian Filosofis tentang Hukum dan Keadilan dari Pemikiran Klasik Sampai Pemikiran Modern," Al-Ihkam J. Huk. dan Pranata Sos., vol. 11, no. 2, pp. 247-274, 2017.

[14] W. N. Dunn, "Pengantar Analisis Kebijakan Publik, edisi ke-2." Terjemahan Samodra Wibawa, Diah Asitadani, Agus Heruanto Hadna dan Erwan ..., 2003.

[15] R. Nugroho, "Kebijakan publik: Formulasi, implementasi dan evaluasi," Jakarta Elex Media Komputindo, 2003.

[16] G. C. Edward III, Implementing Public Policy. Washington: Congressional Quarterly Press, 1980 . 